\title{
Investigating factors for disaster preparedness among residents of Kuala Lumpur
}

\section{E. Mohammad-pajooh ${ }^{1}$ and K. Ab. Aziz ${ }^{2}$}

${ }^{1}$ Institute for Sanitary Engineering and Waste Management, Leibniz Universität Hannover, Welfengarten 1, 30167 Hannover, Germany

${ }^{2}$ Faculty of Management, Multimedia University, Malaysia

Received: 29 March 2014 - Accepted: 4 May 2014 - Published: 27 May 2014

Correspondence to: E. Mohammad-pajooh (pajooh@isah.uni-hannover.de)

Published by Copernicus Publications on behalf of the European Geosciences Union.

\section{Investigating factors for disaster preparedness \\ E. Mohammad-pajooh and K. Ab. Aziz}

Title Page

\begin{tabular}{|c|c|}
\hline Abstract & Introduction \\
\hline Conclusions & References \\
\hline Tables & Figures \\
\hline I4 & \\
\hline Back & Close \\
\hline Full Screen / Esc \\
\hline Printer-friendly Version \\
\hline Interactive Discussion
\end{tabular}




\section{Abstract}

The review of past researches discussed that factors such as climate change and movement toward urbanization will result in more frequent and severe disasters in the near future (Yasuhara et al., 2011). Flash flood is the most common type of disaster 5 that residents of Kuala Lumpur (KL) come across, thus in this study, it was desired to discover the factors affecting preparedness among residents of $\mathrm{KL}$ as well as assessing the variation of individual preparedness among residents. With the aid of SPSS analysis, the reliability of data, correlation and regression analysis between the investigated factors and disaster preparedness were obtained. According to this research it was found that level of preparedness of residents of $\mathrm{KL}$ is still below average; majority of social demographic indicators such as income, education, age, and property ownership showed significant contribution to the variation of disaster preparedness among the residents. For instance men were much more prepared in comparison to women; residents with high level of income and education had also significantly higher preparedness compared to those with low level of income and education. Race was the only factor that differs from the findings of previous studies; since race does not affect the preparedness.

\section{Introduction}

Disaster events are often unexpected and cause human suffering. Furthermore, the 20 occurrence of different types of disasters in both developed and developing countries were predicted to increase due to the effects of climate change, urban planning and industrial development (Chik and Islam, 2011; Said, 2011). Several studies revealed that Asia is more vulnerable than the other continents (World Disaster Report, 2010b). Malaysia due to its geographical location, frequently experience heavy rainfall, which in consequence results in flash floods which interrupts many lives and causes huge economic loss yearly. Not only suffering from the flood but other natural phenomenon
NHESSD

2, 3683-3709, 2014

\section{Investigating factors for disaster preparedness \\ E. Mohammad-pajooh and K. Ab. Aziz}

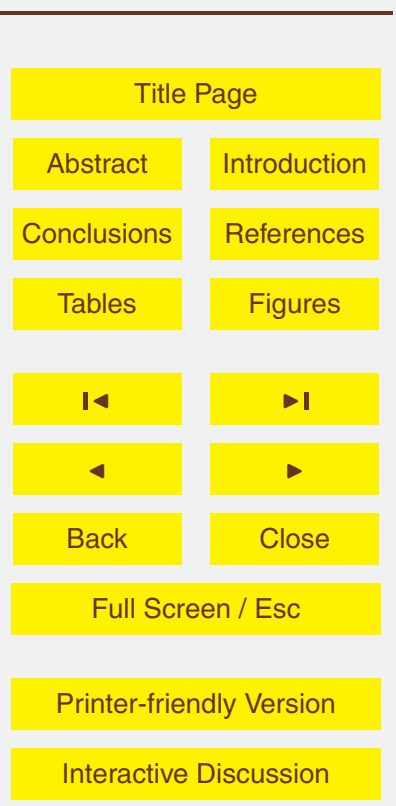


such as landslide, tsunami and smog occurs in Malaysia which will not be addressed in this study.

A study revealed that ordinary citizens can be the first responder to large natural disasters such as flood and preparatory action could be the most cost efficient and 5 sustainable response (WMO, 2008). The study's area of interest is Kuala Lumpur (KL) due to its geographic and strategic importance. In terms of geographical features, KL is located in the west coast of peninsular Malaysia, which is exposed to heavy rainfall especially during the northeast monsoon seasons (October to March). In terms of strategic aspects, Kuala Lumpur is the capital and the economic of Malaysia. KL is 10 considered as the most populated city in Malaysia by having a population of approximately 1.5 to 1.64 million (having 6891 persons km${ }^{-2}$ ) (MARC, 2011; World Health Organization, 2002; CIA fact book, 2012; Malaysian Government Statistics, 2010). By conducting this research, observations can be made on how far it is required to prepare the residents of Kuala Lumpur in order to be able to manage the impact or at least 15 minimize the effects of natural disaster.

\section{Natural disaster in Malaysia}

Under the condition of climate change, more disasters with greater stretches of territory and time have occurred, although the challenges associated with climate change are outside of people's experience but one can simply say that it will pose challenges to human, market and economies (Solechil et al., 2011; Schneider, 2011). The number of people having died due to natural disaster since 1900, reached sixty-two million, which is almost the same as those who were killed in both World War (Cohen and Werker, 2008). According to the World Disaster Report, people living in Asian countries seem to be more exposed to natural disasters. Out of 12 largest disaster events occurred during the period of 2000 to 2010, 8 of those events (nearly $67 \%$ ), occurred in Asia (World Disaster Report, 2010a). Furthermore, the risk of damage from natural hazards such as flood has been increasing in the last decade globally; the increase in severity
NHESSD

2, 3683-3709, 2014

\section{Investigating factors for disaster preparedness \\ E. Mohammad-pajooh and K. Ab. Aziz}

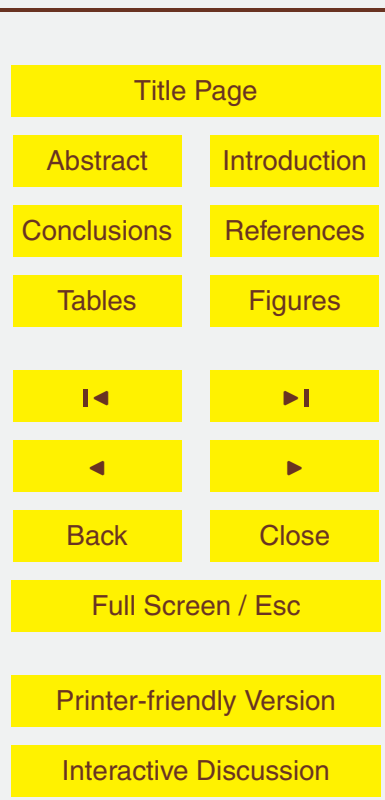


and frequency of such phenomena had been attributed to climate change (Yasuhara, 2011). Malaysia experiences a wide range of natural hazards such as flood, landslide, tsunami and smog but none of them are as economically damaging as flood. According to the International Disaster Database, among the top 10 natural disasters occurred in 5 Malaysia that caused the most loss of lives between 2002 to 2011, 6 of them were floods (The International Disaster Database, 2011).

\section{Disaster and flood preparedness}

Before we go into the flood preparedness concept, it is preferred to briefly explain about the flood disaster, hazard and risk. The flood hazard is the potential of damage of flood or in a simple word a thread; once that thread come into the action and affect the individuals it will be considered as a risk. Thus the flood risk could be defined as the probability that the flood hazard could get into the action and lead to the injury. Once the flood damage revealed and become measurable it will be known as the flood disaster. The degree of flood hazard could be depended on several factors; the level of individual disaster preparedness is one of them. Disaster preparedness could be defined as to what extent individuals are ready to deal with natural or man-made disaster; by forecasting and taking precautionary measure and necessary action before a disaster, individual will be able to respond more effectively and ensure speedy recovery (Frieman et al., 2011; Austin, 2010; Perry and Lindell, 2003; Kent, 2004). As disaster preparedness is simply the state of readiness to deal with a disaster if and when it occurs (Frieman et al., 2011); one may simply say that flood preparedness is the extent to which individuals are ready to act and take preparatory defensive action in advance or immediately prior to a flood threat (Frieman et al., 2011; Schmidlin, 2010).

\section{NHESSD}

2, 3683-3709, 2014

\section{Investigating factors for disaster preparedness \\ E. Mohammad-pajooh and K. Ab. Aziz}

Title Page

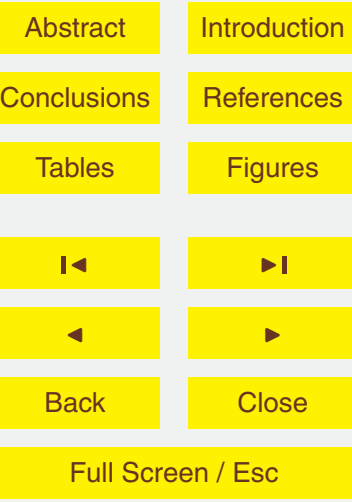

Printer-friendly Version

Interactive Discussion 


\subsection{Perceived risk}

Perceived risk can be defined as how much risk or damage individuals perceived to be caused by a hazard or disaster (Sherman et al., 2011). Most people believe that they are safe and either disaster will not occur or if occur they will not be the one 5 who will be affected, thus they don't take any precautionary activity; the reason behind this matter is that people tend to think that natural disaster such as flood are periodic phenomena and it does not occur randomly (Motoyoshi, 2006; Kano et al., 2009). Studies had shown that awareness of a location's flood risk will enhance the individual's flood preparedness, and furthermore, most people will want to be prepared for possible reoccurrence of the disasters, thus, are more likely to gather information (WMO, 2008; Coulston and Deeny, 2010). Other studies also stated the awareness and knowledge of one's surrounding are very valuable, because it will enhance mental readiness (Digian, 2005). However, studies have shown thatthe factors influencing flood preparedness are not only being adequately informed about the surrounding, but social-demographic characteristics could be also considered as important factors. Individual social-demographic differences (gender, house ownership, education, etc.) will result in inequality in experiencing flood impacts; and the severity of the impact on individuals will depend on the extent of the disaster (Coninx, 2010; Walker et al., 2006; Viswanath et al., 2011).

\subsection{Socio-demographic as a factor of preparedness}

The current population of Malaysia is estimated to be 28.6 million, among which $67.4 \%$ are Malay, $24.6 \%$ are Chinese, $7.3 \%$ are Indians and $0.7 \%$ other ethnics. Among the population $27.6 \%$ are below 15 years old, $67.3 \%$ are between 15 to 64 years old and $5.1 \%$ are 65 years and over (Fox News, 2011; Malaysia Population Clock, 2011).

this variation in socio-demographic characteristics, there should be disparities among individual disaster preparedness with respect to their age, race, education, gender, income. Through the past researches, it was also revealed that disaster prepared-
NHESSD

2, 3683-3709, 2014

Investigating factors for disaster preparedness

E. Mohammad-pajooh and K. Ab. Aziz

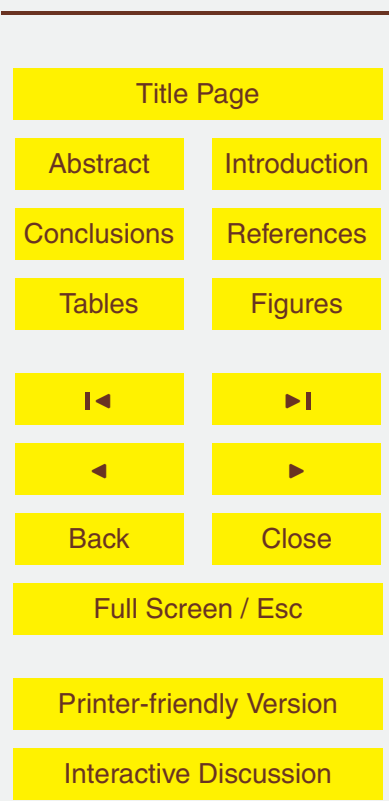


ness could have correlated with certain socio-demographic characteristics such as education, income, gender as well as age of individuals (Mulilis et al., 2000; Motoyoshi, 2006; Schmidlin, 2010; Reese et al., 2010; Digian, 2005; The Macaulay Land Use Research Institute, 2011; Fothergill et al., 1999; DESA, 2004; Baker, 2011). In terms of 5 social demographic, factors such as age, gender, education, level of income, house ownership as well as race will be taken into the account in this study.

\subsubsection{Level of income}

Income could be one the most important factors which shares a relationships with disaster preparedness (Digian, 2005). Many studies found that high income population seems to be more prepared and less vulnerable before, during and even after natural disasters than low income population (Baker, 2011; Rowel et al., 2011; King, 2000). Similar study by Kim and Kang (2010) also expressed the importance of income in a more complicated way; disaster resources could be one of the key elements in disaster preparedness which itself is highly depended on income level. Other studies also stated that people with higher income would have access to more resources such as television, radio as well as car, which assist them in evacuation from vulnerable area (King, 2000). Toya and Skidmore (2007) highlighted the different level of natural disaster impact in two countries that experiencing same level of disaster but having different level of income; the result showed that increase in level of income will result to increase of safety, thus country with less income will have less precautionary measure and will experience more loss during natural disaster.

\subsubsection{Race}

Many studies found that race plays important role in disaster preparedness where, minority groups are likely to be more vulnerable (Viswanath et al., 2011; Austin, 2010; Baker, 2011). This positive correlation between races and preparedness exists due to reliance of race on several factors that highly correlates with disaster preparedness.
NHESSD

2, 3683-3709, 2014

Investigating factors for disaster preparedness

E. Mohammad-pajooh and K. Ab. Aziz

Title Page

\begin{tabular}{c|c|}
\hline Abstract & Introduction \\
\hline Conclusions & References \\
\hline Tables & Figures \\
\hline B & \\
\hline Back & Close \\
\hline Full Screen / Esc
\end{tabular}

Printer-friendly Version

Interactive Discussion 
The main factor could be due to the income level, since socio-economic factors such as income vary among races, and income itself is highly positively correlated with preparedness (Austin, 2010; Peacock et al., 1999; Rowel et al., 2011; King, 2000). Differences in religion, cultural values could be another two reasons for correlation between 5 races and disaster preparedness (Viswanath et al., 2011). Values and cultural differences could influence the preparedness actions; previous study also indicated that current disaster preparedness literatures are in technical language and might not be able to communicate the information effectively (Friedman et al., 2008; Drabek and Mcrntire, 2003).

\subsubsection{Gender}

Among all the socio-demographic factors, role of gender still engaged many researchers' mind; since there are many studies, which confirm the inequalities between the genders and disaster preparedness, and there are many studies which, compete against this finding. The aim of this section will be to explore the gender differences in terms of preparedness when a disaster strikes; however in order to be able to deliver the message of this section, one's should be able to distinguish between the gender difference and sexes. Sex is just referring to biological aspects of being male or female, while gender difference will be the differences in area of actions of sexes, which could be due to different capabilities, rights and decision-making (Mollahosseini, 2011). Many studies examined the gender difference effects on disaster preparedness at the individual level; some of these studies strongly stated that women are less prepared however, other studies rejected this hypothesis (Kano et al., 2009; Austin, 2010; Fothergill et al., 1999). Vulnerabilities among men and women could be varied due to the differences in the role and responsibility they have taken in the society as well as inequality in terms

and and factors of unemployment (World Health Organization, 2002; MARC, 2011). Gender difference seems to be limited in the developed countries; and this could be due to the equality in taking responsibility and similarity in decision-making (Coninx, 2010).

\section{NHESSD}

2, 3683-3709, 2014

\section{Investigating factors for disaster preparedness \\ E. Mohammad-pajooh and K. Ab. Aziz}

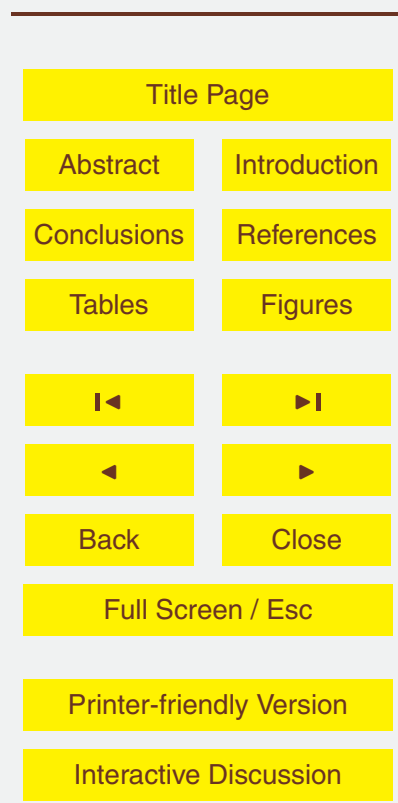


Based on the findings of Wood and his colleagues, men and women in the US are used to making the same decision in disaster preparedness (Austin, 2010). Similar studies with different outcome developed by Oxfam regarding the status of gender inequality and disaster preparedness in Bangladesh; findings showed the vulnerabilities and loss of life during disaster in Bangladesh is more among women, the reasons were due to women's status in the society and racial discrimination against them (Oxfam, 2011).

\subsubsection{Property ownership}

According to many studies this socio-demographic characteristic positively correlates with disaster preparedness; the findings seem to suggest that home owners seem to be more prepared than those who rent the place (Baker, 2011). Another study also emphasized on positive relationship between home ownership and preparedness, however stated that this correlation was not significant (Coulston and Deeny, 2010). The reason that home owners seems to be more prepared than renters could be due to several reasons which all refers back to the responsibilities that owners takes and renters prefer to avoid (Mulilis et al., 2000). Homeowners invest more to protect their property; this investment could be either in terms of construction, providing emergency equipment or acquiring insurance. The relation between property ownership is not limited to only residential area, study revealed that even businesses that own their premises seems to be more prepared than those who lease (Dahlhamer and Souza, 1997). The reason behind is that, owner believes that they have more asset in danger, thus they prefer to participate in more disaster preparedness activities to reduce the risk (Austin, 2010).

\subsubsection{Age}

In case of natural disaster in Asia in near futures, majority of people who get affected 25 will be people below 65 (Goulding and Smith, 2003). Malaysia specifically has $67 \%$ of its population aged between 15-64 years old (Fox News, 2011; Malaysia Population
NHESSD

2, 3683-3709, 2014

\section{Investigating factors for disaster preparedness \\ E. Mohammad-pajooh and K. Ab. Aziz}

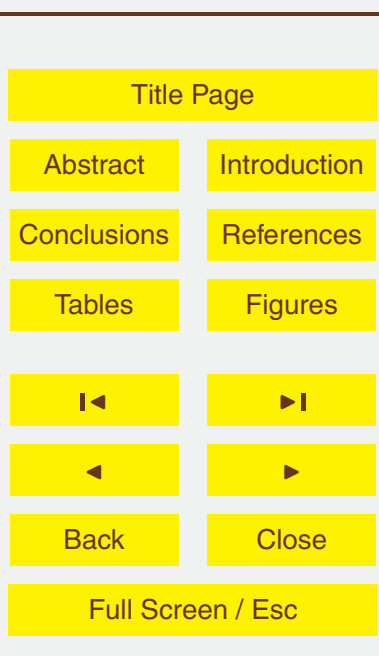

Printer-friendly Version

Interactive Discussion 
Clock, 2011). Many studies revealed that older people seems to be less prepared and more vulnerable in the case of natural disaster, however some studies illustrated that older people are more likely to avoid the negative psychological aspect of natural disaster (MMD, 2008; Bourque et al., 2006; Cutter et al., 2003; WHO, 2008; Norris and 5 Murrell, 1998). Advantages of elder people could be their awareness of their surrounding and their prior experience of natural disaster, which makes them more familiar with natural disaster and as a result gives the ability to overcome the disaster more effectively (King, 2001).

\subsubsection{Education}

10 Studies in the area of disaster preparedness and education found positive correlations between the two. Thus, educated people will have tendency for higher disaster preparedness (Haulihan et al., 2000; Peacock et al., 1999). Importance of relation between education level and flood preparedness have been emphasized by many studies; however, there are more, need to be explored regarding the impact of these two on each other (Coninx, 2010). Several studies illustrated variation in experiencing flood impacts on individuals due to different education level; the differences was mostly due to differences in understanding the dangers of potential hazards, knowledge regarding hazard behavior, preparation techniques, interpreting and receiving flood forecasting, warnings and accessing electronic media (Digian, 2005; Peacock et al., 1999). Lack of information due to the different education level also lead uneducated people to be more disposed to material damage (Thrush et al., 2005).

\subsection{Past experience as a factor of preparedness}

Past experience can increase the preparedness to natural disaster, since it influences people to gather more information about the natural disaster, inform the individual about the probability of occurrence of similar events in future and as a result brings better judgment toward natural disaster preparedness (Weinstein, 1989; Lindell and Perry,
NHESSD

2, 3683-3709, 2014

\section{Investigating factors for disaster preparedness \\ E. Mohammad-pajooh and K. Ab. Aziz}

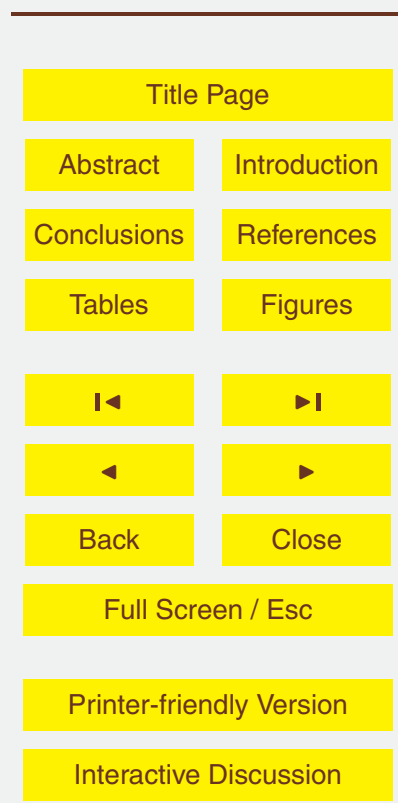

Interactive Discussion 
2000). Although many studies indicated the positive correlation between the past experience and preparedness, there were also minor studies which showed that past experience does not always enhance preparedness of individuals, and addressed such ineffectiveness due to the degree of experience involved (Paton et al., 2001). Prior ex5 perience to disaster might not always directly affect preparedness but its indirect effect has been proved by several studies and it has shown to be one of the preparedness determinants (Lindell and Whitney, 2000). Schmidlin stated in his study of risk factors and social vulnerabilities, women who experienced the flood and have been trapped in their houses during the flooding intended to give special attention to the windows to make 10 sure that they can escape easily in the future in case of flooding (Schmidlin, 2010). Individuals, who also experienced natural disaster and damage of property, seemed to be more attentive to the news than people who did not face natural disaster and property damage (Sattler et al., 1995). In addition, the past experience could be a great asset for the government as well, the experience obtained from the individual could be 15 utilize to improve the response and preparedness of individuals to the future disaster (Said, 2011).

\section{Research methodology}

The research methodology selected for this study are be to test the existence of relationship between the investigated preparedness factors and disaster preparedness of

residents of Kuala Lumpur. In this study, survey method was used to collect data from the residents of Kuala Lumpur. In total, 400 questionnaires were distributed in areas around Kuala Lumpur with high population density, a total of 214 questionnaires were received back, which implies a rate of return of almost $53 \%$.

\section{NHESSD}

2, 3683-3709, 2014

\section{Investigating factors for disaster preparedness \\ E. Mohammad-pajooh and K. Ab. Aziz}

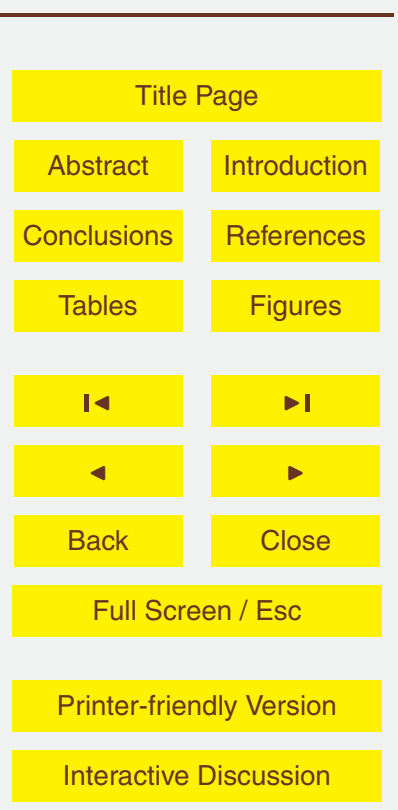




\section{Analysis}

To determine the role of investigating factors on disaster preparedness, the answers returned from the respondents were keyed in Statistical Package for Social Science (SPSS 17.0) Software database. In the examination of the data collected, firstly, items 5 related to the level of preparedness have been grouped and preparedness index has been identified. All constructs were tested for reliability by using the Cronbach Alpha reliability analysis. The results for all constructs in this research showed Cronbach Alpha of nearly 0.70 . Previous studies found for social sciences the overall internal reliability is good when Cronbach Alpha is larger than 0.60 .

\subsection{Preparedness index}

Preparedness index has been obtained by weighting reply to eight index questions; where answers to the index questions have been scaled. The summations of answers to all the questions make up the criteria for how prepared the individuals are; therefore, the individuals who responded with more number of "Yes" and "Very Prepared" obtain 15 the highest preparedness level while those with low number of "Yes" along with "Not Prepared" result in low preparedness level. According to the descriptive statistics, if the highest level of preparedness is considered as 8 and lowest as 0 , it can be said that individuals scoring below 4 could be considered as not prepared since they were not able to even achieve half of the total score. 133 residents (62\%) scored below 4 and reported that they are not prepared, $49(23 \%)$ residents scored moderately and obtained score of 4 , while only 32 residents $(15 \%)$ reported high level of disaster preparedness.

\subsection{Socio-demographic}

\subsubsection{Age, gender and income}

The results showed that there exist a relationship between age and preparedness. It

was observed that as age increased so does the preparedness of residents. It was

\section{NHESSD}

2, 3683-3709, 2014

Investigating factors for disaster preparedness

E. Mohammad-pajooh and K. Ab. Aziz

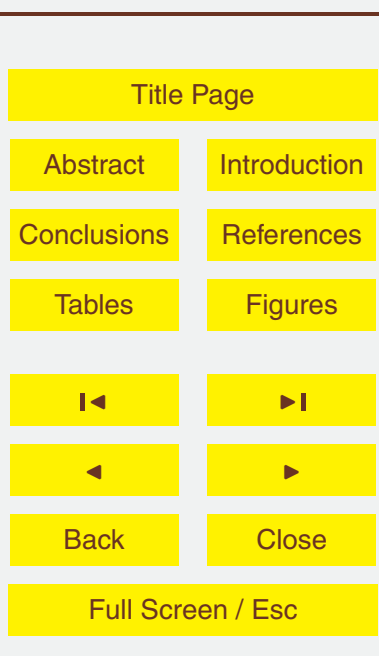

Printer-friendly Version

Interactive Discussion 
found that residents aged below 20 had a preparedness of 1.5 while this preparedness is doubled for people from 30 to 50 . In terms of gender difference, female showed low level of preparedness of 2.68, while male had almost average level of preparedness of 3.37. The residents who have the highest level of income are among the most prepared 5 group with the index of 4.4, while individuals with the range of income below RM 2000 had lowest level of preparedness of 1.7. Residents with the level of income between RM 2000-4000 and RM 4000 to 6000 had preparedness of 3.35 and 3.85 respectively.

\subsubsection{Evacuation plan, type of item in supply kit}

The survey revealed that $56 \%$ of participants have had an evacuation plan, while $44 \%$ have not had any evacuation plan. A high portion of survey participants $(94 \%)$ reported not having a supply checklist, however, $54 \%$ reported to have a survival kit instead. Those prepared individuals who had supply kit seem to have food as the most popular item ( 82 cases) followed by water (77 cases), medical supplies (56 cases), flashlight (47 cases), battery (32 cases), battery powered radio (27 cases) and fire extinguisher 15 (19 cases) as common items in their supply kit.

\subsubsection{Communication channels}

Communication channels could enhance community preparedness by providing information regarding risk, evacuation, etc. Nowadays, many people still refer to TV, radio, newspaper and many others type of communication channels to get the latest information; but the most preferred type of communication channels by residents of Kuala Lumpur was discovered with the help of questions in the last part of the questionnaire. Analysis revealed that a majority of respondents (41\%) prefer to receive information regarding preparedness through the Internet. Respondents mentioned TV as the second point of contact for acquiring information (25\%), while for $21 \%$ of the respondent

\section{NHESSD}

2, 3683-3709, 2014

\section{Investigating factors for disaster preparedness \\ E. Mohammad-pajooh and K. Ab. Aziz}

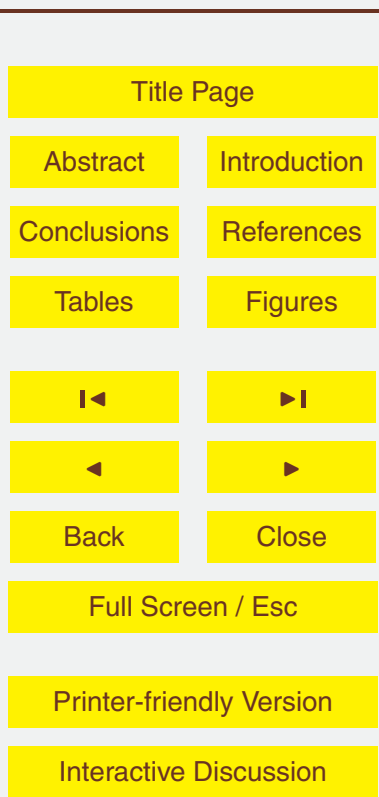


ered as the most effective type of communication channels, since they were accounted for $87 \%$ of response.

\subsubsection{Socio-demographic and disaster preparedness}

Malay and Chinese were considered as the main respondents to this research since 5 they were the majority by responding for 78 cases (36\%) and 65 cases (30\%) respectively. The remaining $34 \%$ were combination of 46 Indian (22\%) and 25 others (12\%). Relationships between socio-demographic characteristics and disaster preparedness have been shown by the Table 1; gender, age, income, education, reading forecast and property ownership significantly correlated with disaster preparedness, while race does not correlate significantly. One of the most obvious correlations that stand out in this study could be the financial conditions of individuals and their preparedness; level of income has the highest correlation with level of preparedness therefore it can be said that income level has the primary influence on disaster preparedness. According to the analysis the strongest relationship between income level and disaster preparedlevel will result in increase in disaster preparedness of individuals. The relationship between education and disaster preparedness produced a Pearson's coefficient of 0.526 , implying that there was strong positive relationship between education and disaster preparedness of individuals, however this correlation could be influenced due to exis20 tence of relationship between level of income and education, analysis indicates a fairly high relationship between these two variables as well.

Age is another factor that also significantly correlates with disaster preparedness. Correlation table indicated a correlation of 0.377 between age and disaster preparedness. Meanwhile, gender and disaster preparedness are positively correlated with 25 Pearson coefficient of 0.243 ; this finding confirms many researchers' findings in which gender and disaster preparedness are positively correlated. However, findings could go against few past researches that stated that due to significant role that women play in today's society, women seem to be equally prepared in case of disaster. Property own-
NHESSD

2, 3683-3709, 2014

Investigating factors for disaster preparedness

E. Mohammad-pajooh and K. Ab. Aziz

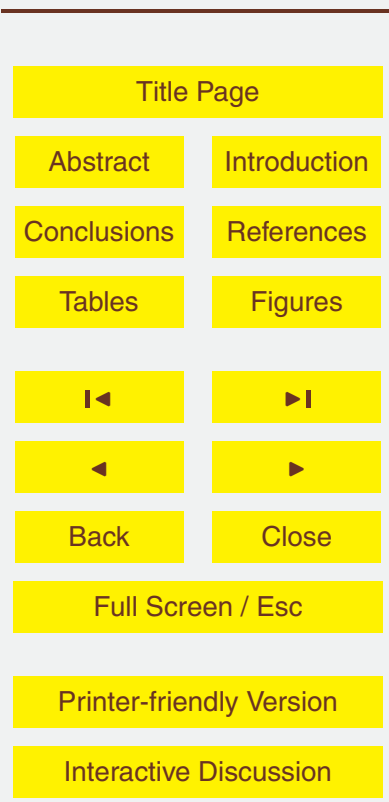

Interactive Discussion 
ership classified into two groups of either owned or rented property. There was a fairly positive correlation of 0.213 between this variable and disaster preparedness. There was also a clear relationship between those who read the forecast and their disaster preparedness; forecast positively correlated with having Pearson coefficient of 0.311 .

5 Many socio demographic factors illustrated relationship with disaster preparedness; however, the correlation of race with disaster preparedness turn out bit complicated since the result turned out a Pearsons coefficient of 0.053 between race and preparedness, thus race could not be considered a major factor that affects the preparedness.

\subsection{Past-experience and disaster preparedness}

10 The following table represents the correlation of past experience with disaster preparedness, better handling subsequent flood and preparedness, report a high correlation of 0.566 , faster evacuation and better reaction toward warning dissemination have also significant positive correlations with preparedness; however minimizing injuries does not have significant correlation with preparedness.

\section{Discussion}

There are several uncertainties involved in this research, first uncertainty is involved in terms of data validation, and since in this study the sample size was quit small, extensive data collection could be a better representative of the outcome. Second uncertainties could be due to the lack of data and activities which itself could affect the estimated level of preparedness, one of these factors could be the evacuation map and its distribution among the residents; according our findings majority of residents did not receive any evacuation map and where not even aware about their surrounding and nearest evacuation routes. Detail study regarding the evacuation routes should be conducted, such as estimating number of people at different places at different time of

\section{NHESSD}

2, 3683-3709, 2014

\section{Investigating factors for disaster preparedness \\ E. Mohammad-pajooh and K. Ab. Aziz}

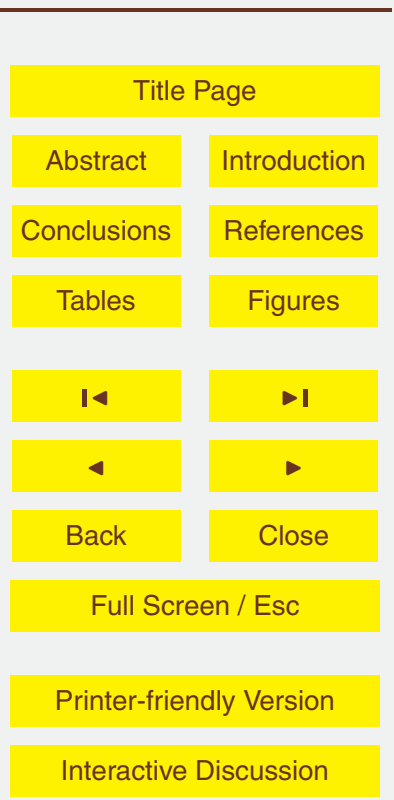


a day in Kuala Lumpur, identifying bottle necks and creating shelters for de-centralized evacuation for regions that reaching to the safe place takes longer than getting flooded.

Not only access to the evacuation route is enough but awareness and knowledge also plays important roles; since how people react to certain warning could vary greatly 5 among the individuals and this could also enhance the vulnerability, especially during the warning distribution. According to our analysis almost $44 \%$ were reluctant to evacuate their property, this could be due to different warning perception, risk perception or even being fearful to get house rubbed. Willingness for evacuation could be also affected by religion since some individuals might live in the belief of fate in God s hand. 10 All the above matters could be considered as one of the socio-economic hotspots of vulnerabilities.

According to this research, it was discovered that the most common problem among people who were flooded was loss of communication (66 cases), followed by evacuation problems (45 cases), lack of food and water (19 cases), medical supplies (14 cases). Proper communication channel must be proposed, especially for regions which do not have access to the communication channels. According to the analysis, majority of the people prefer Internet and TV; however it should be noted that during the disaster there might be the electricity cut-off which disable the warning dissemination, thus the media coverage could be the desired communication channel by residents but not necessarily the applicable one, however, Mosques could be a proper option in Islamic country for disseminating the news especially during the electricity cut off. The above matters could be considered as an example of the government hotspots of vulnerability which itself could affect the level of preparedness.

To be able to evaluate the potential preparedness, it is not enough to focus on only residents; government and past experience could plays important role. Although this was not the main objective of this research, but an interview was conducted with the government authorities. The main point of discussion was addressed to the budget spend for the preparedness activities, preparedness workshops, and current and future flood mitigations projects. The major findings were: 1 . there are less vulnerabilities

\section{NHESSD}

2, 3683-3709, 2014

\section{Investigating factors for disaster preparedness \\ E. Mohammad-pajooh and K. Ab. Aziz}

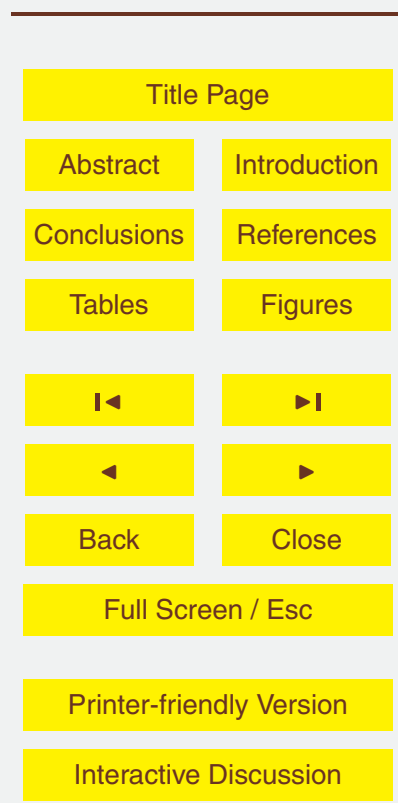


in Malaysian infrastructure due to huge investment in current and future flood mitigation projects; 2. however, "there were several issues such as lack of assigned budget for preparedness activities such as such training for the public" but there are some activities, for instance "whenever DID installs a new gadget, it is desired to gather residents 5 and do the briefing, such as SMS warning services" another example could be "developing and informative website known as infobanjir, in which residents could access the CCTVs and monitor the normal, danger and alert water levels". Lastly, 3 . There is lack of integration among the agencies, "since there is only one annual meeting regarding this matter, which takes a place before monsoon season".

\section{Conclusion}

Malaysia must not only focus on the infrastructure aspect but rather consider both culture and hotspots of vulnerabilities as well; identifying the hotspots of vulnerability and proposing the proper action could lead to increase the level of preparedness in the society. Disaster preparedness attempts to prevent turning the potential risk into the disaster; although significant efforts has been done so far to raise public awareness regarding preparedness of natural disaster, still the level of preparedness of people remains low (WMO, 2008; Lindell and Whitney, 2000). Studies found that even preparedness level of Japanese who are frequently in danger of natural disaster, still remains insufficient (Takao, 2004). According to this analysis, the overall preparedness of residents of Kuala Lumpur is 3.4 and 2.7 for males and females respectively which are less than half of highest level of preparedness. Developing certain strategy for enhancing preparedness of residents of Kuala Lumpur could be vital and could lead to minimize the impact of flood disaster on residents. Government should take multiple approaches to enhance awareness among people: one could be through developing the vulneraevacuation potential of every region and proposing the safe areas and buffer zones; however there could barriers for doing so, such as decreasing the price of the proper-

NHESSD

2, 3683-3709, 2014

\section{Investigating factors for disaster preparedness \\ E. Mohammad-pajooh and K. Ab. Aziz}

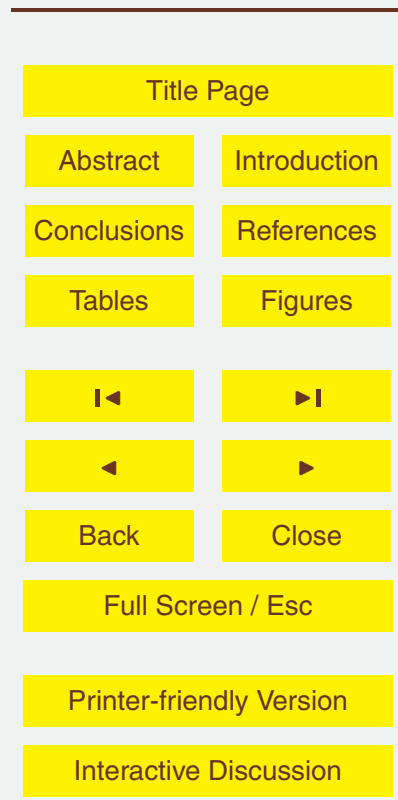


ties which are located in a danger zones and shift of poor population into those area which itself could result into new problem; thus population in the danger areas must be estimated and strategy to reduce accumulation of people on that area must be done. The other approach could be enhancing risk awareness, developing preparedness ac5 tivities (public lecture; training materials, books, educative website and etc.) as well as setting up special groups who can assist and update citizens. Increase in the level of risk perception will enhance the preparedness level, thus it is necessary to keep risk perception at high level, so that individuals always believe that disaster will happen to them and they intend to get more prepared (Reese et al., 2010). Communication 10 gap must be minimized; since individuals will have different educational background, enhancing the education and training could be the key to this issue. Studies showed that a person who is aware of the increased risk for flooding will be more likely to go after collecting information about flooding (Coulston and Deeny, 2010); and this leads the individual to be more psychologically prepared (awareness of one's surrounding) which could be more valuable than being physically prepared (Digian, 2005). Providing a local and global preparedness index in order to investigate to what extend individual preparedness varies in local and global level, assessing appropriate preparedness action in critical location (such as evaluating the preparedness of hospitals) and how they can handle evacuation in case of facing disasters, (for example, museum employees knowledge on saving the valuable items, or the extent of staff and students knowing what to do when a disaster strikes their schools); all and all could lead to more precise evaluation of preparedness in Malaysia.

\section{References}

Austin, D.: Surviving the Next Disaster: Assessing the Preparedness of Community-Based Organizations, 2010.

Baker, E.: Household preparedness for the aftermath of hurricanes in Florida, Appl. Geogr., 31, 46-52, 2011.

\section{NHESSD}

2, 3683-3709, 2014

\section{Investigating factors for disaster preparedness \\ E. Mohammad-pajooh and K. Ab. Aziz}

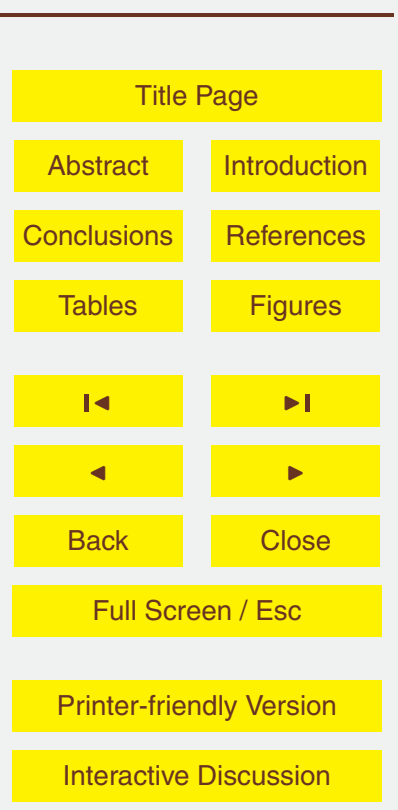


Bourque, B., Siegel, M., Kano, M., and Wood, M.: Morbidity and morality associated with disasters, in: Handbook of Disaster Research, Springer science, New York, 97-112, 2006.

Chik, Z. and Islam, T.: Disaster in Bangladesh and management with advanced information system, Disaster Prevention and Management, 20, 521-530, 2011.

$5 \mathrm{ClA}$ fact book, available at: https://www.cia.gov/library/publications/the-world-factbook/geos/ my.html, 2012.

City Population, available at: http://www.citypopulation.de/Malaysia.html, 2010.

Cohen, C. and Werker., E.: The Political Economy of Natural Disaster, Harvard Business School, 2008.

10 Coninx, I.: WWW Questions on Social Flood Impacts Answered: What, Why and Who?, Katholieke Universiteit Leuven, 2010.

Coulston, J. E. and Deeny, P.: Prior Exposure to Major Flooding Increases Individual Preparedness in High-Risk Populations, 2010.

Cutter, S., Boruff, B., and Shirley, L.: Social vulnerability to environmental hazards, Soc. Sci. 15 Quart., 84, 242-261, 2003.

Dahlhamer, J. and Souza, M.: Determinants of business-disaster preparedness in two US metropolitan areas, International Journal of Mass Emergencies and Disaster, 15, 265-281, 1997.

Department of Statistics Official Statistics Malaysia Official Website: A population distribution and basic demographic characteristic report population and housing census Malaysia [Online], available at: http://www.statistics.gov.my/portal/index.php?option=com_content\&view= article\&id=1215\%3Apopulation-distribution-and-basic-demographic-characteristic-report -population-and-housing-census-malaysia-2010-updated-2972011\&catid=130\%3Apopul ation-distribution-and-basic-demographic-characteristic-report-population-and-housingcensus-malaysia-2010\&lang=en, 2010.

Digian, S.: Socio-economic Variables as Indicators of Preparedness Level in Cyclone Events, James Cook University, 2005.

Drabek, E. and Mcrntire, A.: Emergent phenomena and the sociology of disaster leassons, trends and opportunities from the research literature, Disaster Prevention and Management, $30 \quad 12,97-112,2003$.

EM-DAT: The OFDA/CRED International Disaster Database, available at. www.em-dat.net, Université Catholique de Louvain, Brussels, Belgium, 2012.

\section{NHESSD}

2, 3683-3709, 2014

Investigating factors for disaster preparedness

E. Mohammad-pajooh and K. Ab. Aziz

Title Page

\begin{tabular}{|c|c|}
\hline Abstract & Introduction \\
\hline Conclusions & References \\
\hline Tables & Figures \\
\hline I & \\
\hline & -1 \\
\hline Back & Close \\
\hline Full Screen / Esc \\
\hline
\end{tabular}

Printer-friendly Version

Interactive Discussion 
Fothergill, A., Maestas. E., and Darlington, J.: Race, ethnicity, and disasters in the United States: a review of literature, Disasters, 23, 156-173, 2011.

Fox News, available at: http://www.foxnews.com/us/2011/06/23/churchill-downs-hit-hard-bypossible-twister/\#ixzz1Tas9Tsqc1, 2011.

5 Friedman, B., Tanwar, M., and Richter, V.: Evaluation of online disaster and emergency preparedness resources, Prehosp. disaster medicine, 23, 438-446, 2008.

Frieman, D., Rose, I., and Koskan, A.: Pilot assessment of an experimental disaster communication curriculum, University of South California, 20, 238-250, 2011.

Goulding, R. and Smith, M.: Public health and aging: trend in aging - United States and worldwide, 2003.

Haulihan, J., Lamas, J., and Whife, K.: To What Extent is Earthquake Preparedness Determined by Income and Education, University of Liverpool, 2000.

International Federation of Red Cross: World Disaster Report 2010, 35, 2010a.

International Federation of Red Cross: World Disaster Report 2010, 182-187, 2010b.

15 Kano, W., Mileti, D., and Bourque, L.: Re-conceptualizing household disaster readiness: the get ready pyramid, Journal of Emergency Management, 7, 25-37, 2009.

Kent, R.: Disaster Preparedness, 2nd edn., United Nation Development, GE.94-02897, 2004.

Kim, Y. and Kang, J.: Communication, neighbourhood belonging and household hurricane preparedness, Disasters, 34, 470-488, 2010.

King, D.: You're on you own: community Vulnerability and the need for awareness and education for predictable natural disasters, Journal of Contingencies and Crisis Management, 8, 223228, 2000.

King, D.: Use and limitations of socioeconomic indicators of community vulnerability to natural hazards: data and disaster in northern Australia, Nat. Hazard, 24, 147-156, 2001.

Lindell, M. K. and Perry, R.: Household adjustment to earthquake hazard: a review of research, Environ. Behav., 32, 461-501, 2000.

Lindell, M. and Whitney, J.: Correlates of household seismic hazard adjustment adoption, Risk Anal., 20, 13-25, 2000.

Malaysian Meteorological Department (MMD): Initiatives on Sumatra 2004 tsunami, Putrajaya, 2008.

Malaysia Population Clock, available at: http://www.statistics.gov.my/portal/index.php?option= com_content\&view=article\&id=213\&lang=en, 2011.

MARC: Economic Research on the State of Selangor, 2011.
NHESSD

2, 3683-3709, 2014

Investigating factors for disaster preparedness

E. Mohammad-pajooh and K. Ab. Aziz

Title Page

\begin{tabular}{|c|c|}
\hline Abstract & Introduction \\
\hline Conclusions & References \\
\hline Tables & Figures \\
\hline $\mathbf{1}$ & \\
\hline 4 & $-\mathbf{1}$ \\
\hline Back & Close \\
\hline Full Screen / Esc \\
\hline
\end{tabular}

Printer-friendly Version

Interactive Discussion 
Ministry of Natural Resource Malaysia, available at: http://www.water.gov.my/en/our-servicesmainmenu-252/flood-mitigation-mainmenu-323/programme-aamp-activities-mainmenu-199, 2011.

Mollahosseini, A.: A Survey on the Role of Gender Differences in Leadership Style Selec5 tion and its Leading to Organizationall Crisi-preparedness or Crisis-proneness, 1, 042-047, 2011.

Motoyoshi, T.: Public perception of Flood Risk and Community-based Disaster Preparedness, 121-134, 2006.

Mulilis, J. P., Duval, T. S., and Bovalino, K.: Torando preparedness of students, non-student renters, and non-student owners: issues of PrE theory, J. Appl. Soc. Psychol., 30, 13-29, 2000.

Norris, F. and Murrell, A.: Prior experience as a moderator of disaster impact in anxiety sympotoms in older adults, Am. J. Commun. Psychol., 16, 665-683, 1998.

Oxfam: Handbook of Women Leadership in Disaster Risk Management, ISBN: 978-984-333086-4, 2011.

Paton, D., Jhonston, D., and Bebbington, M.: Direct and vicarious experience of volcanic hazards: implications for risk perception and adjustment adoption, Australian Journal of Emergency, 15, 58-63, 2001.

Peacock, G., Morrow, H., and Girard, C.: Ethnic and racial inequities in hurricane damage and insurance settelments, Routledge, New York, 171-190, 1999.

Perry, R. W. and Lindell. M. K.: Preparedness for emergency response, guideline for the emergency planning process, Disasters, 27, 336-350, 2003.

Reese, S., Johnston, D., Tuohy, R., Becker, J., and Coomer, M.: Flood Perception, Preparedness and Response to warning in Kaitai, Northland, New Zealand: Results From Surveys in 252006 and 2009, 2011.

Roosli, R. and Brien, G.: Social learning in managing disasters in Malaysia, Disaster Prevention and Management, 20, 386-397, 2011.

Rowel, R., Sherikhattari, P., Barber, T., and Evans, M.: Introduction of a Guide to Enhance Risk Comminucation Among Low-Income and Minority Populations. A Grassroots Community En30 gagement Approach, 2011.

Said, A., Ahmadun, F., Mahmud, A., and Abas, F.: Community preparedness for tsunami disaster, Disaster Prevention and Management, 20, 266-280, 2011.

\section{NHESSD}

2, 3683-3709, 2014

Investigating factors for disaster preparedness

E. Mohammad-pajooh and K. Ab. Aziz

Title Page

\begin{tabular}{|c|c|}
\hline Abstract & Introduction \\
\hline Conclusions & References \\
\hline Tables & Figures \\
\hline I & \\
\hline & \\
\hline Back & Close \\
\hline Full Screen / Esc \\
\hline
\end{tabular}

Printer-friendly Version

Interactive Discussion 
Sattler, N., Adams, G., and Watts, B.: Effect of personal experience on judgments about natural disasters, J. Soc. Behav. Pers., 10, 891-898, 1995.

Schmidlin, T.: Risk Factors and Social Vulnerability, Kent State University USA, 2010.

Schneider, R.: Climate change: an emergency management perspective, University of Noth Carolina at Pembroke, Pembrike, North Carolina, USA, 20, 53-62, 2011.

Sherman, M., Peyrot, M., Megda, L., and Gershon, R.: Modeling pre-evacuation delay by evacuees in World Trade Center Towers 1 and 2 on September 11, 2001: a revisit using regression analysis, Fire and safety journal, 46, 414-424, 2011.

Solechil, W., Leichenko, R., and Brien, K.: Climate change adaptation strategies and disaster risk reduction in cities: connection, contentions, and synergies, Current Option in Environmental Sustainability, 3, 135-141, 2011.

Takao, K.: Factors Determining Residents Preparedness for Floods in Modern Megalopolise: The case of the Tokai Flood Disaster in Japan, Disaster Prevention Research Group, 2004.

The International Disaster Data Base, Malaysia Country Profile, available at: http://www.emdat. be/result-country-profile?disgroup=natural\&country=mys\&period=2002, 2011.

The Macaulay Land Use Research Institute: Experiences of Flood Warning Systems and Preparedness for Floods: Survey Findings, Report for Scotland, 2011.

The World Health Organisation (WHO): Older persons in emergencies: an active ageing perspective, 2008.

20 Thrush, D., Bruningham, K., and Fielding, J.: Flood warning for vulnerable groups, Environment Agency, 20, 2005.

Toya, H. and Skidmore, M.: Economic development and the impact of natural disaster, Economic Letters, 94, 20-25, 2007.

United Nations Department of Economic and Social Affairs (DESA): Guidelines for reducing flood losses, 2004.

Viswanath, B., Maroky, A., Math, S., John., J, Cherian, A., Girimaji, B. V., Hamza, A., and Chaturvedi, S.: Gender differences in the psychological impact of Tsunami, Int. J. Soc. Psychiatr., 130-136, 2011.

Walker, G., Fielding, J., Smith, G., Thrush, D., and Fay, H.: Addressing Enviromental inequalities, Flood Risk, Environment Agency, 120 pp., 2006.

Weinstein, N. D.: Effects of personal experience on self-protective behavior, Psychol. Bull., 105, 31-50, 1989.

\section{NHESSD}

2, 3683-3709, 2014

Investigating factors for disaster preparedness

E. Mohammad-pajooh and K. Ab. Aziz

Title Page

\begin{tabular}{|c|c|}
\hline Abstract & Introduction \\
\hline Conclusions & References \\
\hline Tables & Figures \\
\hline $\mathbf{1}$ & \\
\hline 4 & $-\mathbf{1}$ \\
\hline Back & Close \\
\hline Full Screen / Esc \\
\hline
\end{tabular}

Printer-friendly Version

Interactive Discussion 
WMO/GW: WMO/GWP Associated Programme on Flood Management, Urban Flood Risk Management - A Tool for Integrated Flood Management Version 1.0, 2008.

World Health Organization: Gender and Health in Disasters, Switzerland, 2002.

Yasuhara, K., Komine, B., Murakami, S., Chen, G., Mitani, Y., and Duc, D.: Effects of Climate $5 \quad$ Change on Geo-disasters in Coastal Zines and Their Adaptation, Elsevier Ltd, 2011.

\section{NHESSD}

2, 3683-3709, 2014

Investigating factors for disaster preparedness

E. Mohammad-pajooh and K. Ab. Aziz

Title Page

\begin{tabular}{c|c} 
Abstract & Introduction \\
\hline Conclusions & References \\
\hline Tables & Figures \\
\hline $\mathbf{1}$ & \\
\hline Back & Close \\
\hline
\end{tabular}

Full Screen / Esc

Printer-friendly Version

Interactive Discussion 
Table 1. Flood disaster and number affected. Source: EM-DAT, The OFDA/CRED International Disaster Database.

\begin{tabular}{lll}
\hline Disaster Type & Disaster Date & Total Number Affected \\
\hline Flood & $12 / 1965$ & 300000 \\
Flood & $12 / 1970$ & 243000 \\
Flood & $01 / 1967$ & 140000 \\
Flood & $01 / 2007$ & 137533 \\
Flood & $12 / 2006$ & 100000 \\
Flood & $11 / 1988$ & 60000 \\
Flood & $11 / 2005$ & 30000 \\
Flood & $12 / 2007$ & 29000 \\
Flood & $11 / 1986$ & 25000 \\
\hline
\end{tabular}

\section{NHESSD}

2, 3683-3709, 2014

Investigating factors for disaster preparedness

E. Mohammad-pajooh and K. Ab. Aziz

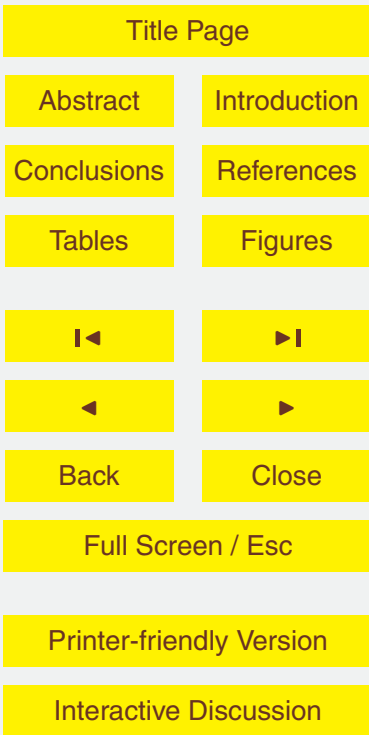




\section{NHESSD}

2, 3683-3709, 2014

Investigating factors for disaster preparedness

E. Mohammad-pajooh and K. Ab. Aziz

Table 2. Socio-demographic correlations. ${ }^{* *}$ Correlation is significant at the 0.01 level (2-tailed).

\begin{tabular}{|c|c|c|c|c|c|c|c|c|c|}
\hline & & Preparedness & $\begin{array}{l}\text { Q1 } \\
\text { Gender }\end{array}$ & $\begin{array}{l}\text { Q2 } \\
\text { Age }\end{array}$ & $\begin{array}{l}\text { Q3 } \\
\text { Race }\end{array}$ & $\begin{array}{l}\text { Q4 } \\
\text { Income }\end{array}$ & $\begin{array}{l}\text { Q5 } \\
\text { Education }\end{array}$ & $\begin{array}{l}\text { Q9 } \\
\text { Rent.or } \\
\text {.Owned }\end{array}$ & $\begin{array}{l}\text { Q10 } \\
\text { Forecast }\end{array}$ \\
\hline \multirow[t]{3}{*}{ Preparedness } & Pearson Correlation & 1 & $0.243^{* *}$ & $0.377^{* *}$ & 0.053 & $0.629^{* *}$ & $0.526^{* *}$ & $0.213^{* *}$ & $0.311^{* *}$ \\
\hline & Sig. (2-tailed) & & 0.000 & 0.000 & 0.440 & 0.000 & 0.000 & 0.002 & 0.000 \\
\hline & $N$ & 214 & 214 & 214 & 214 & 214 & 214 & 214 & 214 \\
\hline
\end{tabular}

Title Page

\begin{tabular}{|c|c|}
\hline Abstract & Introduction \\
\hline Conclusions & References \\
\hline Tables & Figures \\
\hline I4 & \\
\hline 4 & \\
\hline Back & Close \\
\hline Full Screen / Esc \\
\hline Printer-friendly Version \\
\hline Interactive Discussion
\end{tabular}




\section{NHESSD}

2, 3683-3709, 2014

\section{Investigating factors} for disaster preparedness

E. Mohammad-pajooh and K. Ab. Aziz

Table 3. Past-experience correlations. ${ }^{* *}$ Correlation is significant at the 0.01 level (2-tailed).

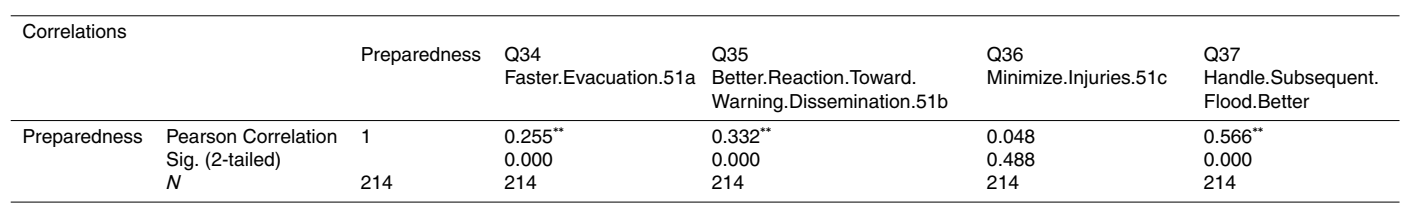

Title Page

\begin{tabular}{|c|c|}
\hline Abstract & Introduction \\
\hline Conclusions & References \\
\hline Tables & Figures \\
\hline I & \\
\hline & \\
\hline Back & \\
\hline Full Screen / Esc \\
\hline Printer-friendly Version \\
\hline Interactive Discussion
\end{tabular}




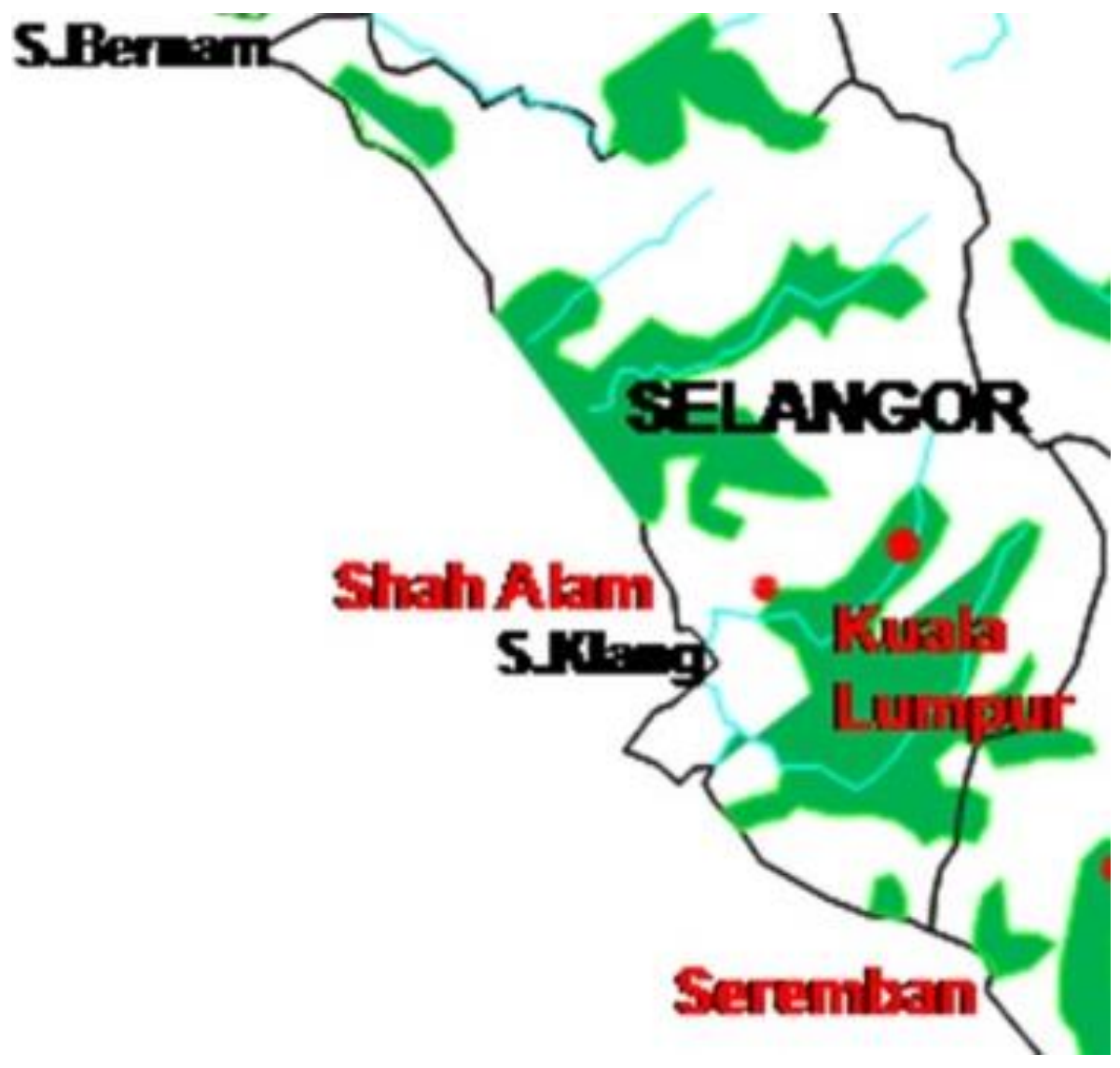

Figure 1. Disaster flood damage area in Selangor. Source: Ministry of Natural Resources and Environment Malaysia.

\section{NHESSD}

2, 3683-3709, 2014

Investigating factors for disaster preparedness

E. Mohammad-pajooh and K. Ab. Aziz

Title Page

\begin{tabular}{|c|c|}
\hline Abstract & Introduction \\
\hline Conclusions & References \\
\hline Tables & Figures \\
\hline & \\
\hline & \\
\hline Back & Close \\
\hline
\end{tabular}

Full Screen / Esc

Printer-friendly Version Interactive Discussion 


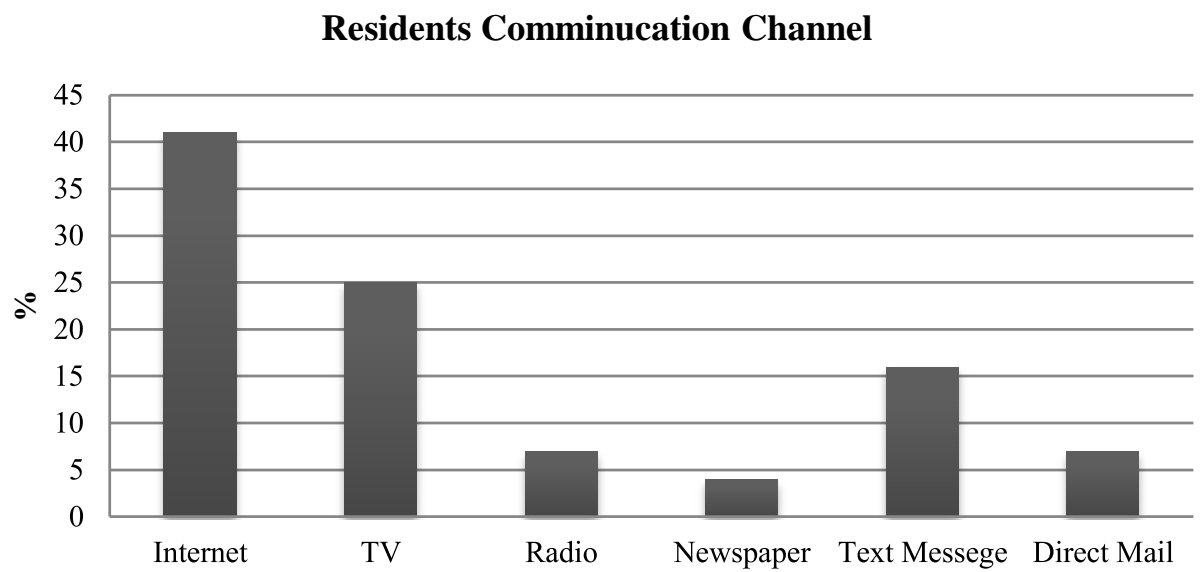

Figure 2. Preferred communication channels by residents.

\section{NHESSD}

2, 3683-3709, 2014

Investigating factors for disaster preparedness

E. Mohammad-pajooh and K. Ab. Aziz

Title Page

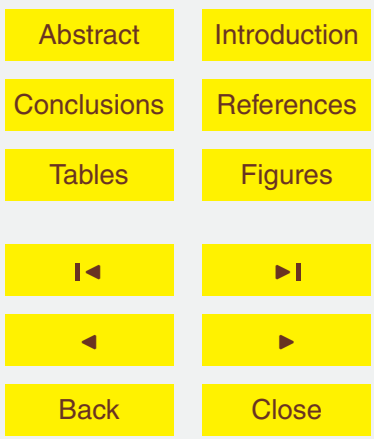

Full Screen / Esc

Printer-friendly Version

Interactive Discussion 